\title{
BILINMEYENI BEKLEMEK: ALFONSO SASTRE'NIN ESCUADRA HACIA LA MUERTE (ÖLÜM MANGASI) OYUNUNDA BELIRSIZLIK
}

\section{SOSYAL BILIMLER DERGISI}

ANKARA UNIVERSITY JOURNAL OF SOCIAL SCIENCES

10.33537/sobild.2020.11.1.3

\section{Makale Bilgisi}

Gönderildiği tarih: Kabul edildiği tarih: Yayinlanma tarihi:

16-12-2019 16-01-2020

Article Info

Date submitted: Date accepted: Date published:

16-12-2019

16-01-2020

31.01 .2020

WAITING FOR THE UNKNOWN: AMBIGUITY IN ALFONSO SASTRE'S ESCUADRA HACIA LA MUERTE

\section{Ceren CCERÇIOĞLU}

Dr. Öğr. Üyesi, Ankara Üniversitesi, DTCF, Batı Dilleri ve Edebiyatları Bölümü, ckaraca@ankara.edu.tr

\section{Anahtar sözcükler}

Alfonso Sastre, içsavaş sonrast İspanyol tiyatrosu, varoluşçuluk, belirsizlik

\section{Keywords}

Alfonso Sastre, Spanish theatre after civil war, existentialism, ambiguity
Öz

1936-1939 yılları arasında yaşanan İspanyol İç Savaşının ardindan Ispanya Avrupa'ya kapilarin kapatır ve içine kapanır. Belirsiz bir geleceğe doğru ilerleyen İspanyol halkı savaş yaralarını sarmaya çalışırken yaşadıkları sefaletten ispeh nemeh nireflilahuM .rudzustumu iyalod nadıksab ev yeni düzen tarafindan susturulmuş, sansür mekanizması bütün sanat dünyasını ele geçirmişti. Böyle bir ortamda kaleme alinan Alfonso Sastre'nin Escuadra hacia la muerte adlı oyunu dönem insanın çaresizligini ve umutsuzluğunu gözler önüne serer. Bu çalışmanın amact İcsavaş sonrasi İspanyol Tiyatrosu'nda Alfonso Sastre'nin önemini vurgularken, Escuadra hacia la muerte oyununda her tarafi bir belirsizlik sisiyle perdelenmiş oyun kişilerinin varolma mücadesini ve onların iktidarla olan ilişkisini ele almaktır.

\section{Abstract}

After the Spanish Civil War (1936-39), Spain closed its doors to Europe. As the Spanish people move towards an uncertain future, they are desperate because of the misery and oppression they are facing while trying to heal the wounds of war. Almost all of the opposition was silenced by the new order and the censorship took over the whole art world. In such an environment, Alfonso Sastre's play Escuadra hacia la muerte reveals the desperation and agony of the people. The aim of this study is to emphasize the significance of Alfonso Sastre in the Spanish theater after the Civil War, while analyzing his characters existential struggle in the veil of uncertainty and their relationship with the authority in Escuadra hacia la muerte. 


\section{Giriş}

Altın Çăg olarak adlandırılan 16. Ve 17. Yüzyıllardan itibaren güçlü bir tiyatro geleneği olan İspanya'da, tiyatro gerek teknik anlamda gerekse sanatsal bağlamda diğer Avrupa ülkelerinden farklı bir seyir izler. Lope de Vega'nin El Arte Nuevo de hacer comedias en este tiempo başliklı kuramsal metniyle birlikte gelişmeye başlayan Ulusal İspanyol Tiyatrosunun her dönemde, her akımda ve her türde vazgeçemediği tek unsur İspanyolluk olacaktır. Muhafazakâr sanatçılar için de yenilikçi sanatçılar için de İspanyol gelenekleri bitmeyen bir kaynak olarak oyunlarda defalarca karşımıza çıkar. 20. Yüzyılın başlarındaki modernleşme hareketlerinin yanında İspanyol tiyatrosu yine geçmişten ve geleneklerden beslenmeye devam eder. Miguel de Unamuno, Ramón de Valle- Inclán gibi yazarların da içinde bulunduğu 98 Kuşağ1 hem düşünsel anlamda hem de yeni teknikler kullanımı açısından sanata yenilikler getirmesine karşın İspanyollukla bağını koparmayı reddeder, aksine köklerine daha da bağlanır. Benzer bir şekilde Avrupa'daki avangart akımların İspanya'daki uygulayıcıları olan 27 Kuşağı yazarları da dile, tiyatro tekniklerine ve üsluba yenilikler getirmelerine karşın yine oyunlarında İspanyol geleneklerine ve İspanyolluğa yer verirler. İçsavaş süresince ve sonrasinda İspanyol tiyatrosu evrensel konulara, varoluş sancilarına ve insanin genel tabiatına yer verse de "İspanyol olmak" hep merkezde yer alır.

İçsavaş boyunca tiyatroyu bir eğitim aracı olarak gören oyun yazarlarının asıl kaygısı maddi kazançtan ziyade, halk1 bilgilendirmektir. Ancak açlik, sefalet, savaş gibi zorluklarla mücadele eden oyun yazarları, savaş sonrasında giderek artan baskılar ve sansür sebebiyle ya sansüre boyun eğer ya sürgüne gider ya da ölümü göze alarak sisteme karşı oyunlar yazmaya ve sahnelemeye devam ederler. $\mathrm{Bu}$ süreçte tiyatro devlet denetimindeki Teatro Oficial (Resmi Tiyatro) ve devletten gizlice sahnelenen Teatro Subterráneo (Yeraltı Tiyatrosu) olmak üzere ikiye ayrilır. Tiyatro'nun yeraltına çekilmesindeki en önemli etken muhaliflerin k1sa süre için de susturulmasıdır: İçsavaşın bittiği yıl olan 1939'da İspanyol hapishanelerindeki tutukluların sayıs1 270.000 civarındadır, hatta bu sayıya yakın oranda pek çok kişi de denetimli olarak serbest bırakılmıştır. Sonraki on yıl içinde bu sayının ciddi oranda azalır, örneğin 1945 yılında tutuklu sayısı 43.000 civarındadır (Tusell, 1999, 40).

Savaş sonrası Çağdaş İspanyol tiyatrosunun en önemli yazarları arasında bulunan Antonio Buero Vallejo, Alfonso Paso ve Alfonso Sastre birbirilerinden çok farklı tiyatro anlayışlarına sahip olmalarına karşın, bir yandan da dönemin tiyatrosunda birbirlerini tamamlarlar (Sastre'de Anderson, 1987, s.7). 1950'lerde Franco yasaklarına rağmen İspanyol tiyatrosunu canlandiran Antonio Buero Vallejo'yu toplumsal gerçekçiliğin temsilcisi Alfonso Sastre takip eder. Özellikle Valle- Inclán'ın mirasçıları olan "gerçekçi kuşak" yazarları, yeni dişavurumcu, grotesk ve öncü varoluşçu tiyatroya kadar Lorca ve Brecht çizgisindeki tiyatroya bağlı kalırlar.
Franco döneminde İspanyol tiyatrosunun ilk etkilendiği akımlardan biri olan Absürd Tiyatro seyircinin büyük beğenisini kazanır. İspanyol tiyatro seyircine çok da uzak olmayan bu tür 98 Kuşağının önemli temsilcilerin Valle-Inclán tarafindan genel hatları belirlenen esperpento akımıla büyük bir yakınlık içindedir. Tiyatro'da Valle-Inclán, resimde ise Goya'nın öncülüğünü yaptığı esperpento gerçeklere konkav bir aynadan bakmayı amaçlar. Bu şekilde, insanların, olayların ve mekânların olduğundan farkl1, komik ve saçma yönleri okura/seyirciye gösterilir. Benzer bir şekilde absürd tiyatro da "gerçeği mantıklı değişmez bir düzen ya da tarihsel evrimi içindeki diyalektik ilişkiler örgüsü olarak değil, anlaşılmayan ve açıklanamayan bir karmaşa olarak görür (Şener, 1998, s.297)”. II. Dünya Savaş1 sonrasındaki kıyamet sonrasını andiran umutsuz bir dünyada, Absürd Tiyatro ortak bilincin tiyatrodaki ifadesi olur.

Absürd tiyatro bir $\begin{gathered}\text { çelişkiler, } \\ \text { sahneye }\end{gathered}$
karşıtlılar hlamının
yansıtılmasıdır. Oyun kişileri hiçbir yere,
dolayısıla içine fırlatıldıları ortama ait
değillerdir, diyalog biçiminde kurulmuş
konuşmalar birbirini karş1lamaz ya da
neden-sonuç ilişkisiyle ilerlemez, oyun
süresi boyunca bütün olup bitenlere
rağmen genellikle ve aslında oyunlarda
"özetlenebilir” ya da ana hatları çizilebilir
bir olay dizisi yoktur, oyunlardaki ilerleyişe
rağmen dramatik anlamda bir gelişmeden
söz etmek genellikle imkansızdır
(Güçbilmez, 2003, s.97).

Absürd tiyatroda parçalanan gerçek, temel birimlerine ayrilarak, yaşamdaki uyumsuzluğu göstermek üzere yeniden düzenlenir. Olay örgüsünden ziyade diyalog, imgeler ve mekanın biçim verdiği bu yeniden düzenleme sayesinde yazar insanın mutsuz, umutsuz, kırılgan ve güvensiz halini gözler önüne serer.

Franco döneminin baskıcı rejiminin denetiminde, Absürd Tiyatro gelişecek ya da geniș halk kitlelerine ulaşacak imkan bulamamasına karşın yine de varlığını sürdürmeyi başarır. Öte yandan bu dönemde geniș kitlelere ulaşan oyunlar da az değildi. Devlet tarafindan desteklenen ve resmiyet atfedilen Ticari Tiyatro yazarları kontrol altında bir nevi seri üretim yaparlar. Devlet tarafindan desteklenmesine ve resmi olarak kabul edilmesine rağmen bu türün yazarları da sürekli gözetim altında tutulur, oyunlarının da her defasında sansür mekanizmasından onay alması gerekir. İçsavaşın pek çok yazarın sürgüne gitmesi ve hatta Falanjistler tarafından öldürülmesi ile 98 ve 27 kuşaklarının kazanımlarını sekteye uğratmasının yanı sıra sansür mekanizması da tiyatronun istediği/özlediği seyirci kitlesine ulaşmasını engeller. Altın Çağ'dan itibaren ara ara duraklamayla karşılașılmasına karşın, güçlü bir tiyatro geleneği olan İspanya'da Ticari tiyatro Franco rejiminin baskic1 havası altında seyirciye bir nefes alma alanı yaratır ve halka sosyallessme imkanı sunarken, her şeyin normal seyrine döndüğü izlenimi verir.

Sansürle beslenen bu yeni rejime karş1 kayıtsız kalamayan ve halkı bilinçlendirmeyi ilke edinen çoğu Marksist ya da Sosyalist muhalif yazarlar ise 1934 yılında 1. Sovyet Yazarlar Birliği Kongresinde 
dile getirilen toplumcu gerçekçi yöntemi benimserler. Başlarda sadece roman yazarları tarafından kabul gören bu akım her türlü biçimcilikten uzak ve ideolojik eserler vermeyi amaçlar. Camilo Jose Cela'nın Arı Kovanı, Luis Romero'nun La Noria ve Rafael Sanchez Ferlosio'nun El Jarama isimli eserleri bu akımın öncüleri olarak kabul edilir. Sanatın ne değil, nasıl olması gerektiği üzerine fikir yürütülür, bu bağlamda devrimci gelişmenin bir parçası olarak görülen toplumsal gerçeklik, diyalektik materyalizmle ve işçi sınıfının eğitimiyle yakından ilişkilidir. Toplumsal gerçekçiler mevcut değerlerin, kurumların ve kişilerin sağlam yapılarına karşın tükenmeye mahkum olduklarını ve sonrasında ise henüz fark edilmese de yeni şeylerin doğacağını göstermeyi hedefliyorlardı. Öte yandan biçimcilik konusunda son derece katı bir bakışa sahip olan Toplumsal gerçekçi yazarlar, biçimle oynamanın ve yeni biçimler denemenin burjuvaziye ait pratikler olduğunu kabul ettikleri için geleneksel gerçekçi yöntemi benimsiyorlard1.

Toplumcu gerçekçilikten yola çıkan Teatro Realista (Gerçekçi Tiyatro), tarihsel açıdan zor bir dönemden geçen İspanyol tiyatrosu için biçilmiş kaftandır. Kilisenin giderek artan hâkimiyeti, resmi kurumlardaki yozlaşma ve amaçsızca yaşayan insanları konu alan eserler toplumsal bilinci uyandırmayı ve geliştirmeyi amaçlamışlardır. İspanyol tiyatrosunda toplumsal gerçekçiliğin öncülerinden Antonio Buero Vallejo Historia de una escalera (Bir Merdivenin Öyküsü) adlı oyununda XX. Yüzyılın ilk yarısında İspanya'daki toplumsal ve varoluşsal öfkenin merkezinde aynı evde yaşayan üç neslin öyküsünü anlatır. Bu akımın bir diğer önemli ismi olan Miguel Mihura'nın Beckett ve Ionesco tiyatrosundan esinlendiği Tres sombreros de copa adlı oyunu ise burjuva sınıfını eleştirirken, İspanyol toplumunun içinde bulunduğu durumu gözler önüne serer.

\section{Çağdaş İspanyol Tiyatrosunda Alfonso Sastre}

İçsavaş sonrası İspanyol tiyatrosu Alfonso Paso, Antonio Buero Vallejo ve Alfonso Sastre olmak üzere üç yazarın etrafında toplanır. Sanat anlayışları ve dünya görüşleri açısından birbirinden son derece farklı olan bu üç yazar birbirlerini tamamlayan bir niteliğe sahiptir. Ticari komedyalarla öne çıkan Alfonso Paso 1960'lardaki avangart hareket doğrultusunda "Nuevo Teatro Español" (Yeni İspanyol Tiyatrosu) hareketi içerisinde yer alır. Antonio Buero Vallejo ise sanatsal arzularına, kaygılarına ve yeteneğine uygun düşen "olanaklı" bir tiyatro yaratır. Pek çok muhalif yazarın eleştirisini alan "olanaklı" tiyatro, sanata uygulanan baskilardan ve sansürden kaçmak için bir nevi otosansür mekanizması oluşturarak, metafor ve alegori kullanımıyla seyirciye ulaşır.

Alfonso Sastre ise İspanyol geleneklerine ters düşen yeni sahne buluşları ve toplumsal ideolojinin giderek muhafazakarlığa kayması sonucunda profesyonel tiyatrolardan ziyade küçük kumpanyalar için oyunlar yazar. Oyunları sık sık sansüre takılan Sastre bir taraftan oyunlar ve denemeler yazarken bir taraftan da çeviriler yayımlar.
1926 y1lında Madrit'te dünyaya gelen Alfonso Sastre'nin en belirgin çocukluk anıları İçsavaşla ilgili olanlardır. 31 Temmuz 1973 y1lında kendisiyle yapılan bir söyleşide Sastre o günlerle ilgili olarak şöyle der:

"Savaşla ilgili en belirgin izlenimlerim açlık ve bombardımanlardı. Bir gün eğer bulabilirsek patates yiyorduk, ertesi gün ise patateslerin kabuklarını. Bombardımanlara gelince on yaşındaki her çocuğu olduğu gibi beni de korkutuyordu (Sastre'de Anderson 12)."

Sastre'nin oyunlarında insanın çektiği acıların ve sosyal adaletsizliğin sonucu olan açlik ve geceleri sokakları kol gezen terörün izlerine sıkça rastlanır. Sastre savaș bașladığı sırada ortaokul öğrenimine devam eder, ancak savaş sebebiyle okul hayatı sekteye uğrar. Eğitimine özel bir okulda devam eden Sastre, bu yeni okulunda daha sonra onun sanat yaşamını etkileyecek Alfonso Paso, Medardao Fraile ve Carlos Jose Costas gibi tiyatroya ilgi duyan arkadaşlar edinir. 1943 yılından itibaren sadece tiyatroyla ilgilenmeye karar veren bu isimlerden Sastre ve Paso ailelerinin baskısından dolayı mühendislik eğitimi almaya basslarlar. Ancak birkaç hafta sonra okulu bırakıp, tiyatroya ağırlık verirler. O yıllarda İspanyol tiyatrosu sansürden dolayı bir çıkmazın içindedir ve bu durumdan rahatsızlik duyan Sastre ve çevresindeki oyun yazarları Arte Nuevo (Yeni Sanat) adını verdikleri bir grup kurarlar. Sastre'nin ifadesiyle "kendilerini çevreleyen şeylere bir hayır deme şekli" (Ruíz Ramón,1997, s.385) olan bu grubun amac1 İspanyol tiyatrosunda köklü değişiklikler yapmaktır. İdealist ve deneysel bir akım olan Arte Nuevo iki y1l boyunca çalışmalarına devam eder ancak maddi olanaksızlıklar sebebiyle amacina ulaşamadan ve İspanyol tiyatrosuna çok da katkı sağlayamadan dağılır. Daha sonraları Sastre tam da bu nedenden Arte Nuevo'yu "anlamsiz bir fenomen"(Sastre'de Anderson,1987, s.13) olarak nitelendirir.

1950'lerde ise Sastre, Jose María de Quinto ile birlikte tiyatro üzerinden toplumsal bilinci uyandırmayı hedefleyen Teatro de Agitación Social manifestosunu yayımlar. Seyirciyi siyasi ve toplumsal durumlara karş1 uyarılmasın1/kışkırtılmasını amaçlayan Ajitasyon tiyatrosunun kökleri Sovyet Devrimine kadar uzanır ve Mayakovsky, Meyerhold, Piscator ve Brecht gibi isimlerce benimsenir (Pavis 473-474). Arte Nuevo'dan sonra tekrar bir araya gelen bu iki isim o dönemde Avrupa'da ünlenmiş ancak İspanyollar tarafindan tanınmayan Miller, Sartre ve Brecht gibi çağdaş yazarların oyunlarını İspanyol halkına ulaştırmayı hedefler. Ancak son derece profesyonel bir yol izlemelerine rağmen, Teatro de Agitación Social k1sa sürede yasaklanır ve sadece teori aşamasında kalır.

Franco döneminde sansürle büyük bir savaş veren Sastre, sanatın içinde bulunduğu yere ve zamana ayak uydurması gerektiğini ve yazarın gerekirse otosansür ya da metaforlar uygulayarak oyunlarını halka ulaştırması gerektiğini savunan Vallejo'nun aksine sansürün sanatçıların bu tutumları sebebiyle normalleştirildiğini savunur. Resmi kurumlar tarafindan konulan sinırları kabul eden sanatçının bu sınırları yasal ve doğal hale 
getirdiğini düşünüyordu. Ancak sonraları bu polemik için şöyle der:

Buero da ben de yanıldık. Her iki tutum da bir şeyleri değiştirmek ve toplumsal hareket için yetersiz kald1. Buero sistem tarafindan yutuldu, bana gelince ben de bir tiyatro yazarı olarak aynı sistem tarafindan durduruldum. Toplumsal değişiklik ihtiyacının karşısında takınılacak tutum siyasi savaş vermektir. $\mathrm{Bu}$ da ne mümkün olan tiyatroyla ne de imkansız tiyatro ile yapilabilir. Tiyatronun siyasi değişimde bir şeyler yapabileceğini düşündüğüm için biraz safım. Şimdi görüyorum ki sanatın toplumsal gücü uzun süre haz veriyor: bir halkın zekasını ve duyarlılığını yükseltebilir ama ona dayatılan kesin savaşlarda pek bir etkisi olmaz. Tabii ki de sanatın hiçbir işe yaramadığını düşünüyor değilim, en basit ifadesiyle benim yarattığım bir işe yaramad1 (Sastre'de Anderson, 1987, s.17).

1960 y1linda Alfonso Sastre yeni bir muhalif sanat çevresi olan Grupo de Teatro Realista'nın manifestosunu yayımlar. Teatro de Agitación Social gibi profesyonel bir yol izleyen Grupo de Teatro de Realista, ideolojik ve sanatsal değeri yüksek çağdaş oyunları Madrit halkına ulaştırmayı hedefliyordu. "Realizmin ve onun biçemlerinin kuramsal ve uygulamalı olarak araştırilmasinı" (Sastre'de Anderson, 1987, s.18) hedefleyen Grupo de Teatro Realista, İspanyol tiyatrosu ile ilgili önemli belgeler yayımlarken bir yandan da dönemin önemli oyunlarının sahnelenmesine yardımcı olur.

Sastre tiyatroyu bir propaganda aracindan ziyade, bir inceleme aracı olarak kullanmış insani deneyimleri aktarırken şiirsel zarafeti bırakmamıştır. Sastre'ye göre dramatik güç karışık sorunlara cevap vermekle değil, sorular sorarak yakalanabilir, bunu sağlamak için de dogmalarda uzaklaşmak ve varoluşçu ve toplumsal dişavurumculuğa başvurmak gerekir. "Entelektüel ve sanatsal çalışmanın anlamının dünyayı açıklamakta gizli" olduğunu savunan Sastre'nin dramatik eserlerinde bu düşüncenin izleriyle sıkça karşılaş1lır. Toplumsal olayların çağdaş insanlar üzerindeki etkisinde insani erdemlerle verilen mücadeleyi konu alan ve analitik ruhla yazılan oyunlarında dogmaya odaklanılmaz. Sastre'nin endişe dolu, sorgulayıc1 ve akılc1 tavr1 onun tiyatrosunu hareket halinde bir diyalektiğin dramatik bir ifadesine dönüștürür (Sastre'de Anderson, 1987, s.20). Bu açıdan Kaufmann'ın "varoluşçuluk bir felsefe değil, gelenekçi felsefeye karşı birbirinden apayrı başkaldırmaya verilen addır (1964, s.5)" cümlesiyle tanımladığ1 varoluşçuluk, Sastre tiyatrosunun vazgeçilmez unsurlarından birine dönüşür.

Anderson Sastre'nin tiyatrosunun kullandiğ1 dramatik teknikler ve tarzı yıllar içinde geçirdiği evrim göz önünde bulundurulduğunda üç dönemde ele alır: 1946- 1949 yılları arası ilk dönem, 1950-1961 yılları aras1 ikinci dönem ve 1962 sonrası üçüncü dönem (Sastre'de Anderson, 1987, s.21). Sastre'nin oyunlarındaki gelişim ve onun siyasi görüşündeki değişiklikler göz önünde bulundurulduğunda Anderson'in üç döneminin yerinde olduğu gözlemlenir.

Sastre Arte Nuevo'da çalıştığ döneme rastlayan birinci döneminde Cargamento de sueños, Uranio 235 adlı eserlerini ve Medardo Fraile birlikte $\mathrm{Ha}$ sonado la muerte ve Comedia sonámbula adlı oyunları kaleme alır. Hareketten yoksun kendini küçük hissettiği ve bunaldığ1 bir dünyayı anlattığı bu oyunlarda kendi acıları içinde dünyadan soyutlanmış insanların hikayelerini konu alır. Duyguların yerinin olmadığı bu tiyatral dünyayı şekillendirmek için Sastre karışık teknikler, rüyalar, falshbackler ve zamanda ve mekanda sapmalar kullaniyordu (Sastre'de Anderson, 1987, s.21-22) .

1950'li yıllardan itibaren Sastre toplumsal bilinci uyandırmaya ve değişime odaklandığı yeni bir döneme geçer. Önceki dönemiyle üslup ve ideoloji açısından benzerlik gösteren La sangre de Dios, Ana Kleiber ve El cuervo oyunlarında hümanist sosyalist düşünce ağır basmaya başlar. Artık daha hareketli ve değişebilen basskaldırabilen insanları konu alan oyunlar kaleme almaya başlayan Sastre'nin bu yeni döneminde oyun kişileri daha gerek düşüncelerinde gerek davranışlarında "daha" özgürdürler. "Dramas de posibilidad" olarak adlandirılan bu yeni dönem oyunları önceki döneminde karş1laşılmayan türden bir sosyal perspektif içerir. Bireyci ve varoluşçu perspektifin her koşulda varlığını sürdürdüğü oyunların amacı "yoğunlaştırılmış bir gerçekçilik"tir. Çağdaş insanın hem bireysel hem de toplumsal gerilimlerini yakalayarak insan deneyimlerinin bu iki ucundan kaynaklanan çatışmaları dramatize eder (Sastre'de Anderson, 1987, s.22-23). Escuadra hacia la muerte, La mordaza, Tierra rojo, Guillermo Tell tiene ojos tristes gibi oyunların alışılmış bir yapıları olmamasına karşın, Aristoteles'in üç birlik ve trajik duygu kuralları üzerine kurulmuşlardır.

1962 y1lında Sastre Miguel Servet'in hayatını konu alan epik bir oyun olan La sangre y la ceniza'yı kaleme almaya başlar. Üç yıl üzerinde çalıștığı bu oyun ile Sastre sade gerçekçiliği ve Aristotelesçi kuralları bir kenara bırakır, ironiyi ve yabancılaştırma etkisini kullanmaya başlar. Yabancılaștırma etkisi dramatik etkiyi arttırmak için seyirci ile oyun arasına mesafe koymayı gerektirir (Perk, 2018, s.48). Artık Sastre tiyatrosunun başlica öğelerine dönüşen yüksek sesli ve 1ş1klı efektler, uyumsuz stiller, çok sayıda sahneler bulunur. Brecht sonrası bir tiyatro üretebilmek adına ruhsal şiddet ve ironiyi güçlendirmek için kimi zaman esperpentoya yaklaşır. Bu son dönemde uzun cümleler yerine kelimelerin tek tek kullanılması, oyunların kahramandan yoksun oluşu dönem tiyatrosunda bir devrim niteliği taşımaktadır (Sastre'de Anderson, 1987, s.23-24)

\section{Belirsizlik sisine doğru Escuadra hacia la muerte}

Sastre kendisine gelen bir teklif sonrası Londra'da sahnelenmek üzere kaleme aldığı oyunun ilk taslağındaki oyun kişilerinin soyadlarını Londra planinin iptal olmasinin ardindan İspanyolcalariyla değiştirir: Er Adolfo Lavin (Reyes), Er Pedro Recke (Lopez), Er Luis Foz (Garcia), Er Javier Gadda (Romero), Er Andres Jacob (Gonzalez). İspanya'da ise 
oyun üç temsil yaptıktan sonra yasaklanır ve uzun yıllar seyirciyle buluşma imkanı bulamaz.

Toplumun çeşitli sınıflarından insanları temsil eden oyun kişilerinden Javier üniversitede profesördür, Andres üniversite öğrencisidir, Adolfo tüccardır, Pedro işçidir, Luis ise aylak bir gençtir. Franko döneminde entelektüeller ya sürgün edilmiş, ya öldürülmüş ya da bastırılarak köşelerine çekilmişlerdir. Çoğu asker kaçağ1 olan entelektüelleri oyunda Javier temsil eder. Javier'in intiharı yalnızlığın ve çaresizliğin bir sonucu olmasının yanı sıra eli kolu bağlanmış entelektüellerin çaresizliğini sembolize eder. Dönemin tüccarlarını temsil eden Adolfo içsavaş sonrası kapılarını dünyaya kapatan İspanya'da tüccar sınıfın halkın zor durumundan faydalanarak, karaborsacilık ve stoklama yaparak para kazanmasının bir eleştirisidir. Adolfo da bu duruma uygun olarak arkadaşlarının ekmeğini sattığı için cezalandırılmış ve bu birliğe gönderilmiştir. Üniversite öğrencilerini temsil eden Andres'in konuşmalarından öğrenci hareketlerinde yer aldığı anlaşılır. Gençliği sebebiyle hayatı ciddiye almayan Andres yılbaşı gecesi onbaşı Goban'a karşı çıkar ve onbaşının ölümü ile sonuçlanacak tartışmayı başlatır. Luis ise Franco döneminde yetişen gençleri temsil eder. Tecrübesizliği ön planda olan Andres, Dünya ile bağlantısı kopmuş, yüzeysel bir karakterdir. Dönemin İspanya'sindaki falanjist rejimin, diktatörlüğün, baskıcılığın neden olduğu düzeni, disiplini ve otoriteyi oyun kişilerinden Onbaşı Goban temsil eder.

İki perdeden oluşan oyun her biri işledikleri çeşitli suçlardan düșman sınırına gönderilen bir onbaș1 ve beș erin kiyametvari bir ortamda gelecek destek birlikleri beklerken varoluşlarını sorgulamasını konu alır. Bir zaman sonra umutlarını yitiren erler sinır hattına aslında ölümü beklemek için gönderildiklerine, kimsenin desteğe gelmeyeceğine ve aslında bu sonu hak ettiklerine ikna olurlar. Üçüncü Dünya Savaş1 sonrasında, karanlık bir ormanda bulunan bir kulübede geçen oyunda zamanın ve mekanın belirsizliği bir sis gibi bütün oyunu etkisi altına alır. Oyunda her şey belirsiz ve kimliksizdir. Ne mekan ne zaman ne de oyun kişileri hakkında kesin ya da tam bir bilgi yoktur.

Sastre'nin "bir 1stırabın sahneye konması" (Sastre'de Anderson, 1987, s.21) olarak nitelendirdiği Beckett tiyatrosundan esinlendiği dönemde kaleme aldığı Escuadra hacia la muerte, Godot'yu beklerken'de olduğu gibi neyi beklediğini bilmeyen ama çaresizce beklemeye devam eden insanları konu alır. Godot'yu beklerken'de "görünmez bir güç, ara sıra komik yüzlerini ortaya çıkaran ara sıra kaderleri hakkında felsefi yorumlar yapan oyun kişilerinin insanlığını elinden alır (Lawson, 1976, s.23)." Escuadra hacia la muerte de tam da böyle bir yerden yazılır ancak bu oyunda beklenen şeyin değişken adları vardır; oyunun başında destek birliklerini ve neye benzediği bilinmeyen düşmanı beklerler, oyunun sonlarına doğru ise Sulh mahkemesini ya da ölümü. Yine de oyunun bașından beri aslında buraya ölmek için gönderildiklerini düşünürler.

Sastre'nin Escuadra hacia la muerte'yi yazarken etkilendiği tek yazar Beckett değildir, oyun Sartre'ın Türkçeye Çıkış Yok/ Gizli Oturum olarak çevrilen Huis Clos oyunundan da izler taşır. Huis Clos'daki gibi bir mekanda ölmeden sıkışıp kalan oyun kişilerinden Andres ve Javier oyunun 2. sahnesinde Sartre'in cehennemine benzeyen bu yerde içinde bulundukları durumun ölümcül uğursuzluğunu tekrar ederler:

\section{ANDRÉS}

$\mathrm{Bu}$ bir fare kapanı. Çıkış yok, kurtuluşumuz yok. JAVIER

$\mathrm{Bu}(. .$.$) doğru. Bizler ölüme mahkum$ edilmiş bir birliğiz. ANDRÉS

Hayır, daha da kötüsü..., ölümü beklemeye mahkumuz (Sastre, 1987, s.115).

Oyunun yapısına işlenmiş ikilemler ve varoluşçu itirazların boyutu Sastre'nin düşün dünyasındaki iki önemli nokta etrafında şekillenir. Bir tarafta felç olmuşluk ve umutsuzluk, diğer tarafta hareket ve umut, bu ikilem yazarın iki ideolojik eğilimi arasında bir köprü kurar. Bu ikilem oyunun 3. sahnesinde Javier'in ağzından birliğin yaşadığı şu şekilde aktarılır:

Hepimiz bir eve kapatılmış sessiz
insanlara benziyoruz ama aslında
yürüyoruz, her geçen gün ilerliyoruz. Biz
ölüme mahkum edilmiş bir birliğiz.
Disiplinli bir şekilde, bir delinin, onbaşı
Goban'ın sesine itaat ederek yola devam
ediyoruz (Sastre, 1987, s.86).

Sessizliğin ve emirlerin gölgesindeki bu ilerleyiş, esasen eserin disiplin sağlayıcısı Onbaşı Gobán aracılığıla yıkıma ve yok oluşa giden bir yoldur. Oyunun başından itibaren düşman hattında destek birliklerini bekleyen askerler yavaş yavaş umutsuzluğa sürüklenirken, seyirci askerlerin varoluş krizleriyle gelişen deneyimlerini gözlemler.

Oyun boyunca gerçekleşen tek dramatik olay onbaşının öldürülmesidir. Oyunun ortasında gerçekleşen bu cinayet dramatik yap1 bakımından alışılmadık ve etkileyicidir; bir piramidi andıran dramatik yapıda onbaşının ölümüne kadar olaylar gittikçe yükselirken ikinci perdede ise tam tersine aksiyondan uzaklaşılır. Birinci perdede özgürlüğe (hareket) karşı olan baskı (hareketsizlik) tırmanırken, ikinci bölümde felç olmuşluk ağır basar. Dramatik açıdan ikinci perdenin sonu, birinci perdenin başlangıcının tekrarıdır, askerler içinde bulundukları durum içinde hareketsiz ve yetersizlerdir.

$\mathrm{Bu}$ dramatik simetri oyundaki esas belirsizlikleri karş1larken, oyunun toplumsal varoluşçu ve metafizikle birlikte yorumlanmasina neden olur. Daha büyük ve genel bir şeyin sembolü olan birlik aynı zamanda insanin durumunun bir ironisidir. Beklenmeyen ani bir isyanın sonuçlarını sorgulayan oyun militarist zorbalığa karşı bir başkaldırı çı̆̆lığı olarak yorumlanmıștır (Sastre'de Anderson, 1987, s.29). Devrimci düşüncesi belirsiz olan oyun toplumsal düzenin iki uç noktasını adalet perdesine yerlesstirirken adaletin ne anarşinin ne de diktatörlüğün baskısı altında özgür olamayacağını ifade eder. 
Oyunda hiçbir askerin yaptığı hareketten dolay1 varoluşçu bir kurtuluşa ulaşamaması, bu zayıf ve yozlaşmış adamların ahlaki açıdan cezalandırılmış olmalarından kaynaklandığı düşünülebilir. Ancak bu adamların ne için ölüme mahkum edildikleri belirsizdir, cezalandırma mekanizmasının nasıl bir şey olduğu hakkında da ne onların ne de seyircinin bir fikri yoktur. Öyleki suçluluk duygusunun hukuk sağlayıcı bir mekanizma olarak işlediği de varsayılabilir. Bu noktada Foucault'nun Cezalandirmak neye diyoruz? metnine bakmanın faydası olabilir: :

Bizim çağdaş toplumlarımızda biri cezalandırıldığında ne yapıldığı ve aslında, kural olarak, cezalandırmayı, doğrulayacak şeyin ne olduğu tam olarak bilinmemektedir; ve her şey öyle cereyan eder ki sanki biz cezalandırmayı, farklı tarihlerden ayrı dönemlerden, ayrışan rasyonaliteden kaynaklanan ve birbirleri üzerinde az çok tortulaşmış bazı heterojen fikirlere değer kazandırmak için uyguluyormuşuz gibidir (Foucault, 2012, s.256-257).

$\mathrm{Bu}$ bağlamda erlerin suçlarının ne olduğunun bir önemi yoktur, onlar zaten ölüme mahkumdurlar:

\section{LUIS}

Pedro, bütün bunlar ne için? Daha önce ne yaptık? Bunu ne zaman hak ettik? Bunu hak ediyor muyduk Pedro?

PEDRO

Hih! Sormaya gerek yokki. Ne içinmiş? Cevabı yok (Sastre, 1987, s.129130).

Ölüme doğru bunaltıcı bir hareketle son hareketsizliğin beklentisi içinde hayali bir geçitten geçerler. Neyi bekledikleri, ne için nöbet tuttukları, neyi özledikleri belirsizdir:

\section{JAVIER}

(...) çok uzaktayız..

PEDRO

Neyden uzaktayı? (Sastre, 1987, s.

Oyunda savaş insanlara ait bir süreç olmaktan çıkar ve metafizik bir baskı sebebiyle daha da korkunç bir metafora dönüşür. Anlamsız ve uzun nöbetlere boyun eğen erlerin tek çıkışları "hiçbir yere varmayan yollardır". Bu belirsiz havada görünmeyen, anlaşılmayan bir düşmanın varlığı ve bu varlığın dehşeti onları giderek sarar:

Zalim ve vahși olduklarını söylüyorlar. Ama o zamana kadar bilemeyizki... Bizden kaçıyorlar, en çok korku veren de bizden kaçması zaten. Akıllarının başka bir şekilde çalıştığını biliyoruz... İşte bizi endişelendiren de bu, çünkü onları ölçemiyoruz, onları tanımlayamıyoruz ve zihnimizde onları canlandırıp onlara hakim olamiyoruz... (...) Her șeyi yapabilirler ama hangi konuda yetenekliler? Hangi? Eğer bunu bilseydik o zaman korkabilirdik... ama ben korkmuyorum... ac1 çekiyormuşum gibi... bir çatışmada ölmek değil en kötüsü... beni şu anda en çok sikan hayat kalmak..., esir düşmek..., çünkü beni nasıl öldüreceklerini hayal bile edemiyorum... (Sastre, 1987, s.79).

Oyunun tansiyonunun en yükseldiği an olan onbaşının cinayeti, onbaşıyı kurban yaparken erleri de katile dönüşür. Y1lbaşı gecesinde sarhoş olan dört er katı kurallardan, disiplinden, itaatten ve beklemekten yorulmuşlardır. Onbaşının küçümseyici sessizliğini koruyarak kendine hakim olmaya çalışırken saldırıya uğrar. Sastre bu saldırıyı beş adımda görsel olarak şu şekilde kurgular: 1. Bıçak darbesinden kör olmuştu. 2. Sallandı ama düşmedi. 3. Yavaş yavaş yiğıldı. 4. Diz üstü düştü. 5. Yüzükoyun (Sastre 102). Bu sahne tiranlığa başkaldıran küçük insanların ona karşı ayaklanıp onu devirmesinden çok daha fazla anlam içerir. Askerler onbaşıyı öldürerek sefaletten kurtulacaklarını düşünürler, fakat daha sonra gerçek düşmanın onbaşı olmadiğının ve onu ortadan kaldırmakla çok gereksiz bir davranışta bulunduklarını ve her şeyin tam tersine döndüğünün farkına varırlar. 2 . Perdenin başında Andres cinayetin gerçek anlamına dikkati çeker:

Son çıkışı kapattık! [...] Bütün olanlardan sonra zamanın geçebileceğini ve hücum birliklerinin gelmeyeceğini fark ettim; Şubatta bizi geri çekebilirlerdi... bizi affedebilirlerdi... ceza tamamlanmış olacakt1...(Sastre, 1987, s.105).

Öte yandan, intihar etmeden k1sa bir süre önce Javier, onları kuşatan otorite ve disiplinle kurulu düzenin kaybolmasının varlıklarını anlamsızlaştırdığı şu şekilde ifade eder: "O yaşarken mutlu bir varlığımız vard1. Sadece itaat etmek ve acı çekmek yetiyordu (Sastre, 1987, s.124)."Javier onbaşıya Tanrı'nın bir temsilcisi gibi görürken ona ilahi bir anlam yükler. Nietzschevari bir tekrarla Tanrının kısıtlamalarından ve kurallarından sıkılan modern insanlık onu öldürür. Modern insan özgür kaldıktan sonra lanetli birliğin erleri gibi kendinin nasıl düzenleyeceğini bilmediği anarşik bir dünyada bulur (Sastre'de Anderson, 1987, s.34).

Oyunun sonuna doğru erler de belirsizlik sisinin içine doğru çekilmeye başlar. Javier, 10. Sahneden sonra görünmez, sahne dişında kendini asar. Andres ve Adolfo 11. Sahneden itibaren silikleşmeye başlarlar, belirsiz bir kadere doğru yol alırken gözden kaybolurlar. Pedro 12. Sahnede bu kayboluşu "sanki toprak onları yutmuştu (Sastre 129) şeklinde tasvir eder ve "ben de yok olacağım (Sastre, 1987, s.129)" diyerek oyun boyunca havada dolaşan belirsizlik sisinin onu da yutacağını ifade eder. Oyunun sahnelenmesinden yaklaş1k on y1l sonra Sastre şöyle yazar:

Bugün sahneye konmasindan yaklașık on yıl sonra (...) Escuadra hacia la muerte'yi daha farklı bir tarzla yazacağımı düşünüyorum. Savaşa ve onunla ilgili düşüncelere yine reddedici bir akışıyla değinirdim. Yine çıkarc1 yöneticilerin kalplerine dokunurdum. Ancak yine bir 
barış çağrısı, pozitif bir barış önerisi özelliği taşırdı. Belki de oyunun son sahnesi - bugünkü oyunlarımda olduğu gibi- bilinçlendirmeye yönelik olurdu. Ve Luis sonunda duygusuz bir suçlu olan zavallı bir çocuk olmazd1 (Sastre'de Anderson, 1987, s.24).

Pek çok yazar ve eleştirmen Escuadra hacia la muerte'yi dönemin Avrupa'sinın bir alegorisi olarak kabul eder. Juan Emilio Aragones "Escuadra hacia la muerte'de her şeyden önce 1946'dan bu yana Avrupa gençliğinin yaşadiğı geçici durumun sertçe yansımasinı görmekteyiz (Sastre'de Anderson, 1987, s.25)." şeklinde ifade ederken, Ignacio Aldecoa şöyle der:

A.S.'nin Escuadrasinin arkasinda tarihi zamanımızın acı ve tatlı meyveleri saklıdır. Dünyanın sürüklendiği düşünmekten kaçtığımız bir felaketin trajik güvenliği bugünün insanının belirsizliği ve umutsuzluğu onu belki de ertesi gün gelecek ölüme mahkum bir manga kurmaya mahkum ediyor (Sastre'de Anderson, 1987, s.36).

Ölüme mahkum edilen birlik ve günümüz insanının kıyaslanması Sastre tarafindan da Escuadra hacia la muerte'deki diyaloglar vasıtasıyla doğrulanır: "Sizi temin ederim, bunun gibi cephe boyunca pek çok birlik var. Hususi bir vaziyet içinde olduğumuzu düşünmeyin. Başımıza gelenin hiçbir önemi yok (Sastre, 1987, s.116).” $\mathrm{Bu}$ ifadeyle Sastre oyundaki insanların yaşadıklarının münferit ve onlara özel bir durum olmadığını, onlar gibi pek çok kişinin var olduğunu vurgular. Sastre oyun sahnelendiğinde bu genelleme hakkında şöyle yazar:

Birleşmiş bir Avrupa ve hayali bir üçüncü güç için askere alınmayı hayal etmek gereksiz şu anda. Avrupa gençliği iki ateş arasında çalışıyor. İş öğreniyor, karşı ç1kıyor ve kariyer yapmaya hazırlanıyor. Bunların hepsinin savaş tehdidi altındayken ne anlamı var? Escuadra hacia la muerte'de cevaplar verilmiyor ancak en azından bazı trajik soruların köklerine iniyor (Sastre'de Anderson, 1987, s.26).

\section{Sonuç}

İçsavaş sonrası İspanyol Tiyatrosunun en önemli isimlerinden olan Alfonso Sastre çocukluğunu savaş döneminde geçirmiş ve o dönemdeki hatıralar belleğine kazınmıştır. Çağdaşı diğer oyunlarının aksine daha doğrudan ve daha siyasi bir tiyatro yapmayı tercih eden Sastre sik sik İspanya'daki sansür mekanizması tarafından susturulmuştur. Yazıldığı dönemde sadece üç kere temsil edilme şansı bulan Escuadra hacia la muerte ise zamanin ruhunu en iyi yansitan oyunlarından biridir. Kapalı kalmışlığı, umutsuzluğu ve belirsizliği işleyen oyun sahte bir III. Dünya Savaş1 sırasında geçer.

Sastre'nin altı kişiyi bir kulübeye hapsettiği oyunda otoritenin temsilcisi olan Onbaşı Goban, militarizmin ve iktidarın sesidir. Neyi neden istediği belli olmayan ve sürekli katı kurallar çerçevesinde hareket eden bu karakterin öldürülmesiyle oyun bir belirsizlik evreninden başka bir belirsizlik evrenine geçiş yapar. Cinayetten önce ve cinayetten sonra olmak üzere ikiye bölünen oyunda, cinayet öncesi hayatlarının hiç olmazsa bir amacı olduğuna inanan erler, cinayetten sonra artık tamamen kapana kısıldıklarına ve oradan asla kurtulamayacaklarına inanırlar. Düzen koyucunun ortadan kalkmasıla kaosa sürüklenen oyun kişileri belirsizliğe doğru sürüklenirler.

Dönemin İspanya'sının içinde bulunduğu durum göz önünde bulundurulduğunda İspanyol halkının gelecekle ilgili beklentileri tam bir belirsizlik içindedir. Ülkenin diktatörlükle yönetilmesi ve ülkenin bütün geleceğinin tek adama bağlı olması bu belirsizliğin ana kaynağıdır. $\mathrm{Bu}$ açıdan yazıldığı dönemin toplumsal kaygilarını ve gerçeklerini yansitan oyun, insan doğasını, hayatın anlamını ya da anlamsızlığını ve günümüz insanının kapana kısılmışlık hissini didaktik bir üslup yerine bir gözlemci gibi uzaktan ve yalın bir şekilde gözler önüne serer.

\section{KAYNAKÇA}

Aragones, J. E. (1963). El teatro profundizado de Alfonso Sastre, Punta Europa, VIII/83, 24-35.

Güçbilmez, B. (2003) Absürd Tiyatro'da İroni, Tiyatro Araştırmaları Dergisi, 15, 96 -137.

Foucault, M. (2012). İktidarın Gözü. (Işık Ergüden, Çev). İstanbul: Ayrıntı Yayınları.

Kaufmann, W. (1964). Dostoyevski'den Sartre'a Varoluşçuluk. (Akşit Göktürk, Çev.). İstanbul: De yayınevi.

Lawson, J. H. (1976). Teoria y Tecnica de la Dramaturgia. La Habana: Editorial Arte y Literatura.

Pavis, P. (1988) Diccionario del teatro. Dramaturgia, estetica y semiologia. (Fernando de Toro, Çev.). La Habana.

Perk, D. (2018). Savaş Sonrası Alman Edebiyat1, Bat1 Kültür ve Edebiyatında 20. Yüzyıl. Ankara: Ankara Üniversitesi Basimevi, 41-50.

Ruíz Ramón, F. (1997). Historia del Teatro Español. Siglo XX. Madrid: Catedra.

Sastre, A. (1987). Escuadra hacia la muerte. La mordaza. Madrid: Editorial Castalia.

Şener, S. (1998). Dünden Bugüne Tiyatro Düşüncesi. Ankara: Dost Kitabevi Yayınları.

Tusell, J. (1999). La España de Franco. Madrid: Historia 16. 